\title{
A New Penthrite Grenade Compared to the Traditional Black Powder Grenade: Effectiveness in the Alaskan Eskimos' Hunt for Bowhead Whales
}

\author{
EGIL OLE ØEN ${ }^{1}$
}

\author{
(Received 14 September 1994; accepted in revised form 23 February 1995)
}

\begin{abstract}
The Alaskan Eskimos catch bowhead whales of the protected Bering-Chukchi-Beaufort Sea stock using oldfashioned weapons and grenades filled with black powder. Killing is sometimes a lengthy process, and in some years relatively large numbers of animals are lost. A new grenade containing the explosive penthrite was developed for the Eskimos' traditional weapons and first tested in the bowhead whale hunt in 1988, when eight whales were killed by penthrite grenades. Seven of these were landed, and one dead whale was lost. Five whales died instantaneously or within five minutes. Tissue and organ damage was inspected by post-mortem examination. Although data collected after 1988 are less reliable, the survival times recorded for animals landed up to 1992 were markedly shorter for the penthrite grenade than for the traditional black powder grenade. Median survival times were 62 minutes for whales killed by black powder grenades and 15 minutes for those killed by penthrite grenades; $21 \%$ and $45 \%$ of the animals, respectively, were recorded as dead within five minutes, and $32 \%$ and $19 \%$, respectively, were lost. The penthrite grenade is likely to become a highly effective weapon for the bowhead whale hunt, although further modification and testing will be needed before large-scale use. An educational and training programme for all prospective users should also be arranged. The possibility of improving other catch equipment to reduce whale loss should also be considered.
\end{abstract}

Key words: bowhead whale, Balaena mysticetus, Eskimo traditional subsistence hunt, Alaska, hunting method, black powder grenade, penthrite grenade

RÉSUMÉ. Les Eskimos de l'Alaska chassent la baleine boréale de la population protégée des mers de Béring, des Tchouktches et de Beaufort au moyen d'armes à l'ancienne et de grenades remplies de poudre noire. Il faut parfois beaucoup de temps pour tuer l'animal, et certaines années un nombre relativement élevé d'animaux sont perdus. Une nouvelle grenade contenant de la pentrite a été mise au point pour les armes traditionnelles des Eskimos et testée durant la chasse à la baleine boréale de 1988, au cours de laquelle huit baleines ont été tuées par des grenades à la pentrite. Sept ont été ramenées à terre, la huitième a été perdue. Cinq baleines sont mortes sur le coup ou en moins de cinq minutes. Les dommages aux tissus et aux organes ont été relevés par autopsie. Bien que les données recueillies après 1988 soient moins fiables, la durée de survie enregistrée pour les animaux ramenés jusqu'en 1992 était nettement plus courte avec la grenade à la pentrite qu' avec la grenade traditionnelle à la poudre noire. La durée moyenne de survie était de 62 minutes pour les baleines tuées par des grenades à la poudre noire, et de 15 minutes pour celles tuées par des grenades à la pentrite; 21 et 45 p. cent respectivement des animaux étaient classés comme morts en moins de cinq minutes; 32 et 19 p. cent respectivement étaient perdus. La grenade à la pentrite va probablement devenir une arme très efficace pour la chasse à la baleine boréale, bien que des modifications et des essais restent à faire avant de pouvoir l'utiliser à grande échelle. Il faudrait aussi prévoir un programme d'éducation et d'entraînement pour tous les usagers éventuels. Il faudrait également considérer la possibilité d'améliorer le reste de l'équipement de chasse pour diminuer le nombre de baleines perdues.

Mots clés: baleine boréale, Balaena mysticetus, chasse de subsistance traditionnelle des Eskimos, Alaska, méthode de chasse, grenade à la poudre noire, grenade à la pentrite

Traduit pour la revue Arctic par Nésida Loyer.

\section{INTRODUCTION}

The bowhead whale (Balaena mysticetus) is a large right whale that may reach $20 \mathrm{~m}$ in length and weigh up to about 100 tonnes. The skin and hypodermis are about $2 \mathrm{~cm}$ thick and may be very tough in large, old animals. The blubber layer may be $15-70 \mathrm{~cm}$ thick (Reeves and Leatherwood, 1985).

The Bering-Chukchi-Beaufort Sea stock of the bowhead whale was classified as protected stock by the International Whaling Commission (IWC) in 1977. Although the IWC's
Scientific Committee has recommended a zero catch, the Eskimos have been allocated a quota for their traditional subsistence hunt. According to the latest estimates, the stock numbers 6400-9200 whales with a "most probable" estimate of 7500 animals (Eberhardt and Breiwick, 1992; IWC, 1992a) and the quota for the three-year period 1992-1994 was 141 animals, with a supplement for any unused strikes from 1989 to 1991 . In each of the three years, up to 54 animals could be struck (killed or wounded), but no more than 41 whales could be landed per year (IWC, 1992b). For the years 1995-98, the

${ }^{1}$ Norwegian College of Veterinary Medicine, P.O. Box 8146, Dep, 0033 Oslo, Norway

(C) The Arctic Institute of North America 
total number of landed whales shall not exceed 204, with a decreasing rate of strikes from maximum 68 whales struck in 1995 to 65 in 1998. However, unused strikes (maximum 10) can be carried forward and added to the strike quota for any subsequent years (IWC, in press).

In spring, bowhead whales migrate northwards from the Bering Sea to the Beaufort Sea and Amundsen Gulf where they remain until the southerly migration begins in early autumn (Fraker and Bockstoce, 1980). From 1995 on, ten villages along the northern and western parts of Alaska will participate in the hunt. When the whales are expected in spring, the boats and hunting equipment are moved out to camps, sometimes several kilometres from the villages, along leads in the land-fast pack ice where the hunters wait. The boats, called umiaks, have wooden ribs covered with skin and can accommodate 6-8 people; they are stationed, fully equipped, at the ice edge. When the hunters see whales in the leads, they launch the boats and paddle or sail close to a whale before harpooning it. When the whale is dead, it is towed in to land-fast ice and drawn up with the help of rope and pulleys. In autumn, when the whales migrate southwards and the ice has disappeared from the coastline, more modern methods are used. The fall hunt takes place farther from land, using modern boats with powerful outboard or inboard motors. When a whale is towed up on to land for butchering, both tractors and trucks are used if available.

The weapons used by Eskimos to hunt bowhead whales in Alaska were introduced by American whalers in the late 1800s (Mitchell and Reeves, 1980). The weapons consist of two grenade launchers - the "Darting Gun" and the "Shoulder Gun" (Fig. 1a,b) - and a lance or spear. The lance is used in the final phase of catching to pierce the animal's heart and lungs. The grenades (Fig. 2a,b) for the two guns are virtually identical, but the shoulder gun grenades are equipped with stabilizer vanes. Black powder (Dobratz, 1981) is traditionally used as the explosive in the grenade.

The darting gun consists of a grenade launcher fixed to a wooden pole (about $2 \mathrm{~m}$ long) (Naval Company, n.d. $a, b$ ). A harpoon with a rotating head is attached under the gun barrel. A line connected to a buoy is attached to the rear end of the harpoon, and the harpoon line is coiled up in the boat or around the buoy. This weapon fastens the harpoon to the whale and discharges the grenade into the whale's body almost simultaneously. It is thrust into or thrown at the whale from close range, usually aimed at the neck or chest.

The shoulder gun is a hand-held weapon that is fired from the shoulder like a shotgun (Lytle, 1984; Naval Company, n.d. $a, b$ ). According to the Alaska Eskimo Whaling Commission (AEWC) Management Plan (AEWC, 1991), the shoulder gun should not be used before a line has been secured to the whale with a harpoon. The weapon is not very precise, and the shooting range should therefore be limited. If the whale does not die rapidly, several shoulder gun grenades may be fired into the whale.

During hunting the boats are idled up to the whales and the darting gun is thrown. The harpoon, which projects $40-50$ $\mathrm{cm}$ in front of the darting gun barrel, hits and penetrates the
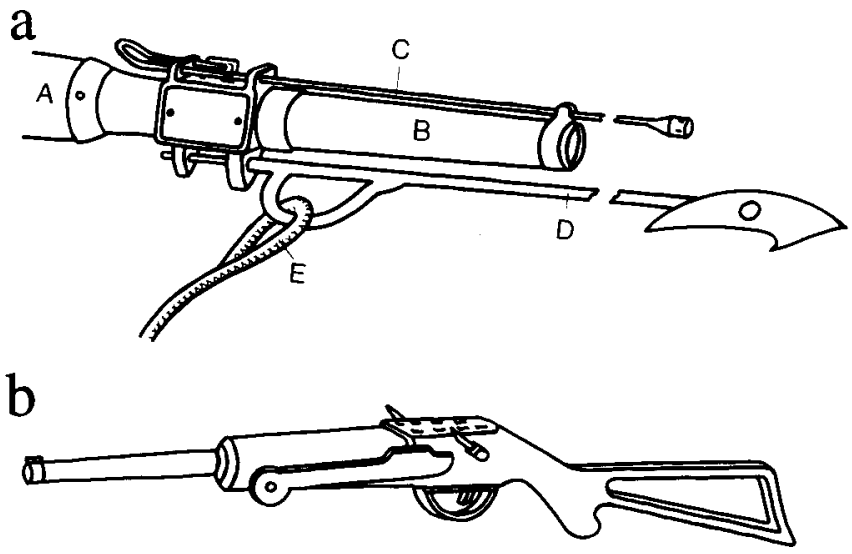

FIG. 1. Darting gun (a) and shoulder gun (b) used by Alaskan Eskimos in subsistence hunting of bowhead whales. A: wooden shaft, B: gun barrel, C: trigger bolt, D: harpoon, E: harpoon line.

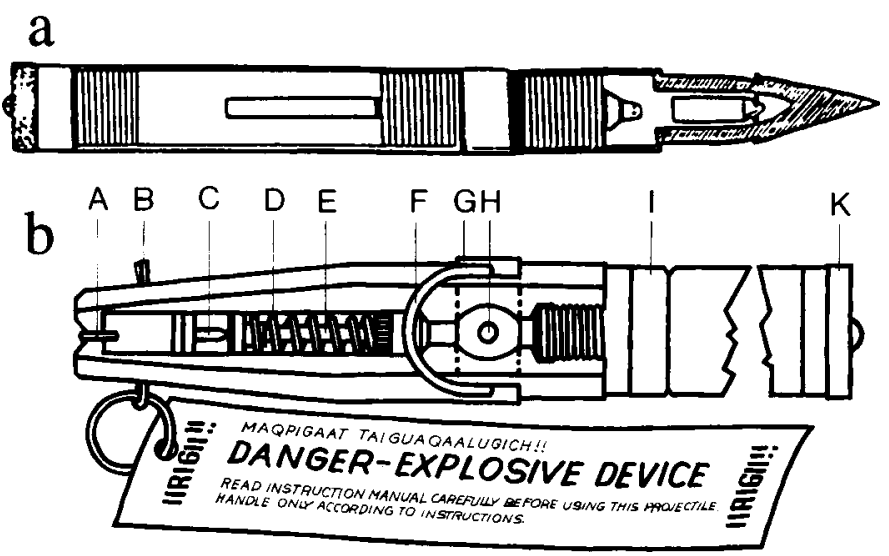

FIG. 2. Longitudinal section view of black powder grenade (a) and penthrite grenade (b) used by Alaskan Eskimos in subsistence hunting of bowhead whales. A: shear-pin, B: split pin, C: firing pin, D: spring, E: delayed fuse, F: steel shackle, G: cylinder, H: instantaneous detonator, I: front plug, K: leather washer.

skin before the trigger rod, which also projects in front of the muzzle, hits the skin and fires the gun, discharging the grenade into the whale's body. The harpoon separates from the gun, which falls into the water, to be retrieved later. The harpoon line uncoils as the whale dives, and the float is thrown overboard. The grenade explodes after a delay of a few seconds.

When animals are shot at such close range as in the bowhead whale hunt, one would expect both a high degree of accuracy and rapid death in most cases, if the weapons are effective and used correctly. However, this does not always appear to be the case. In general, survival times are relatively long and many animals are lost. During the period from 1968 to 1983,378 whales were landed and $311(45 \%)$ were lost (Follmann and Manning, 1989) after having been wounded or killed. Very high losses were recorded in some years: $61 \%$ in 1974, 65\% in 1975 and 74\% in 1977, when a total of 111 animals were recorded as being shot but only 29 landed (Tillman, 1980). During the period from 1983 to 1987, 74 
whales were landed and $46(38 \%)$ were lost. The percentage loss in these years varied from $29 \%$ to $52 \%$ (George et al., 1990). In the middle of the 1970s hunting activity increased significantly. The number of boats increased from 45 to 58 , and the number of animals struck from 47 to 111 per year (Tillman, 1980). The relatively high rate of loss may be explained both by the old-fashioned hunting equipment used and by climatic conditions, but the increased competition and the fact that many new hunters probably did not have adequate experience of hunting and weapon preparation and use probably contributed to the sharp increase in the loss rate in the 1970s.

The AEWC, which coordinates the bowhead whale hunt in Alaska, has introduced measures to improve killing methods and reduce the rate of loss of whales, such as stricter hunting regulations and improved training for new hunters. Work to improve the hunting equipment has also been started. This has included attempts to improve the traditional black powder grenade (IWC, 1985) and the development of a radio transmitter (Follmann and Manning, 1989) and an acoustic pinger (Follmann, 1989) for the floats in the harpoon lines, to enable whales that are not killed quickly or are lost to be found more easily. The use of radio transmitters gave encouraging results already during the first year, when two whales that had been lost were tracked and recovered (Follmann and Manning, 1989). However, experiments with the new black powder grenades were stopped when one person was injured by the premature detonation of a grenade (IWC, 1986).

The supersonic explosive penthrite (Baytos, 1980; Dobratz, 1981) had already been used in harpoon grenades with good results, both for minke whales (Balaenoptera acutorostrata) (Kano and Hasui, 1982; Øen, 1984, 1985, 1994, in press) and for sei whales (Balaenoptera borealis) and fin whales (Balaenoptera physalis) (Øen, 1987). During the annual meeting of the IWC in 1986, it was suggested that penthrite should also be tried in the bowhead whale hunt (IWC, 1987a). The AEWC thereafter initiated the development and testing of a penthrite grenade for use in the Alaskan Eskimo bowhead whale hunt. Development started in 1986, and the first hunting trials began in the spring of 1988 and continued until 1992. No whales were killed with penthrite grenades in 1993. This article describes, as far as the incomplete data permit, the results of the bowhead whale hunt in the years 1984-86 with the traditional black powder grenade (IWC, 1987b) and in the years 1988-92, both with prototypes of the penthrite grenade and with the traditional black powder grenade.

\section{MATERIALS AND METHODS}

When the development of a penthrite grenade for bowhead whales was started, it was understood that the grenades were to be used in the darting gun. The penthrite grenade and its safe and arming mechanism (SAM) previously developed (Øen, 1994) and used for minke, fin and sei whales could not be adapted to this type of weapon. It was therefore necessary to develop a new grenade with SAM. The project was planned in cooperation with the AEWC at the end of 1986 and beginning of 1987. Practical work on the development of the grenade started in 1987 in Norway.

The penthrite grenade consists of two parts, the SAM (head) and the grenade with an explosive charge (Fig. 2b). The two parts are kept separate during transport and storage and assembled before use. Both the SAM and the grenade underwent test programmes and shooting tests at proving grounds before shooting trials using dead sei and fin whales in Iceland. Weapons for the trials were supplied by the AEWC.

The first hunting trials using prototypes in 1988 were conducted with crews appointed by the AEWC and in areas where landed whales could be inspected post-mortem by scientific personnel from the North Slope Borough's Department of Wildlife Management in Barrow, Alaska. Prior to the hunting season, an instruction course was held with hunters selected by the AEWC. Instruction manuals (Øen, 1988a,b) and slides were distributed and the entire course was recorded on video film (AEWC, 1988). Questionnaires were prepared for the collection of data on strike and detonation sites, survival times, depth of the wound, animals' reactions, organ damage, loss of meat and blubber as a result of the detonation, and the hunters' own comments. The criteria the hunters used to establish time of death were that the flippers sagged or that the animal sank or surfaced with the belly upwards. When the whale dived after being struck, however, it could take a few minutes before these criteria could be checked (B. Rexford, Chairman of the AEWC, pers. comm. 1990).

The grenades for the field trials in 1988 were loaded with $10 \mathrm{~g}$ and $15 \mathrm{~g}$ penthrite, and from 1989 onwards, with $20 \mathrm{~g}$ penthrite. Unfortunately the questionnaires had not been distributed to the hunters in 1988, but data for the whales shot with penthrite grenades were obtained by means of interviews with hunters at landing sites and by post-mortem examination. It was, however, not possible to collect data for the black powder grenades in the same way as for the penthrite grenades, since they were mainly used in districts where it was difficult to conduct the same post-mortem inspection of landed animals. Data for the black powder grenades for 1988 and later years were therefore extracted from hunting reports to the AEWC and notes made by AEWC personnel. Time-to-death data for landed whales shot with black powder grenades had been collected in the years 198486 (IWC, 1987b) and since statistical analyses showed that the values for the black powder grenades from this period were very similar to corresponding values recorded in the years 1988-92, these data were pooled and analyzed together.

Since 1988, it has not been possible to collect data on the use of the penthrite grenade as systematically as in 1988. In 1989 , the AEWC chose to distribute penthrite grenades to all hunters who wished to use them. The development had not been completed and no reliable reporting system on its use had been established, nor were new users given any systematic instruction. Data collected after 1988 are therefore less reliable than the 1988 data. Various sources of error may increase the risk of misinterpretation, and the data are liable to be selective and therefore biased. 
Records from 1989 show that penthrite grenades were used for 12 whales and black powder grenades for 14 whales (Department of Wildlife Management, 1990). After spring 1990, it is not known how many animals were shot with penthrite or black powder grenades each year. All the data for penthrite grenades in this study from 1989 or later have been extracted from hunting reports to the AEWC, new report forms introduced in 1991 and notes from the AEWC. However, the hunting reports contain little detail and nearly half the reports received by the author, many of which were originally telephoned to the AEWC's office in Barrow, do not state the grenade type or the survival time. With a single exception (when a watch was used), survival times were only roughly estimated by the hunters. In 1991, the only reports on penthrite grenades are four accounts of grenades that did not function satisfactorily. Although these are not likely to be representative of all penthrite grenades used in that season, they have been included here.

I noted that some penthrite grenades used in the period 1989-90 were used in weapons that were unsuitable because the barrels were too long. Incidents were also recorded in which the wrong type of powder was used as the propellant charge. However, it was not always possible to distinguish incorrect and correct use, and all data are included in this paper. There are no records of the use of the wrong type of weapon in 1988, but in one case an excessive propellant charge was used.

\section{RESULTS}

In the period $1984-86,70$ whales were struck, all with black powder grenades. Of these, $43(61 \%)$ were landed (George et al., 1990). Survival times are known for 38 of the whales landed (IWC, 1987b). In the period 1988-92, 188 whales were recorded as being struck and $132(70 \%)$ of these were landed. Survival times were recorded for 76 whales. Of these, 38 were struck and killed with traditional black powder grenades and 38 were struck with penthrite grenades. Seven of the whales struck with penthrite grenades had already been shot at with traditional black powder grenades. After reshooting with penthrite grenades, five of these died instantaneously, one after five minutes and one after fifteen minutes.

Survival plots for whales shot with black powder grenades (76) and penthrite grenades (38) for which survival times were recorded are shown in Figure 3. The percentage of animals recorded as dead instantaneously or within five minutes and survival times for whales killed with the penthrite and black powder grenades are shown in Table 1.

The survival curves for the penthrite and black powder grenades in Figure 3 illustrate the difference in the effect of the two grenades and show that the penthrite grenade killed a higher percentage of the whales instantaneously. Moreover, animals that did not die instantaneously were nevertheless killed more rapidly by penthrite than by black powder grenades. Table 1 shows that the percentage of whales killed instantaneously or within five minutes increased when penthrite grenades were used, and the median survival time dropped to a quarter of that recorded for the black powder grenade. The longest recorded survival times for both black powder and and penthrite grenades were recorded for whales that were lost and later retrieved and killed.

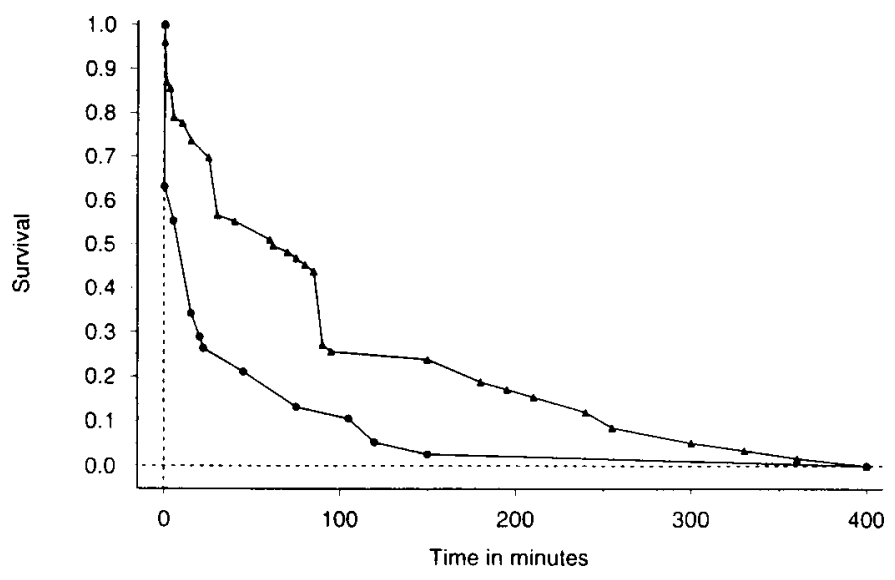

FIG. 3. Survival plot for bowhead whales shot during subsistence hunting by Alaskan Eskimos with prototypes of the penthrite grenade (•) in 1988-92 and with traditional black powder grenades (A) in 1984-86 (IWC, 1987b) and 1988-92. Each $\bullet$ or $\boldsymbol{\Delta}$ represents one or more whales. Two whales which survived 24 hours, one from each group, fall outside this graph.

The average size of the 76 whales killed by traditional black powder grenades was $11.4 \mathrm{~m}$ (range $7.3-17.5 \mathrm{~m}$ ). On average, five black powder grenades were used per whale in the two periods. In one case, 24 grenades were used for the same animal. In $1984-86,18 \%$ of the black powder grenades failed to function. The percentage of malfunctions in 1988 1992 is unknown, but cases of grenade malfunction were recorded in most of the incidents in which more than three shots were used.

The average size of the 38 whales killed with penthrite grenades was $12.6 \mathrm{~m}$ (range 7.8-19.8 $\mathrm{m}$ ). On average, 1.3 penthrite grenades were used per whale, and the maximum number used for one whale was three. There were no reports of malfunctioning or technical problems involving penthrite grenades in 1988, but nine grenades were reported to have malfunctioned from 1989 to 1992 . The survival times for whales shot with defective grenades were generally above the median value.

The influence on the survival time of the covariates grenade type and whale size is illustrated in Figure 4. The analysis, which is based on Cox regression for selected values for animal size, showed that the penthrite grenade killed both smaller and larger whales significantly more rapidly than the traditional black powder grenade.

Since the 1988 season was the only one when all information on the effect of penthrite grenades was collected immediately after the whales were landed, the results are considered more reliable than those for other seasons. Therefore, the 1988 season will be considered in detail.

In 1988, penthrite grenades were used for eight whales (Table 1). Four whales were shot with a single $10 \mathrm{~g}$ penthrite 
TABLE 1. Survival times and percentage of whales dead $\leq 5 \mathrm{~min}$ for bowhead whales shot during subsistence hunting by Alaskan Eskimos with prototypes of penthrite grenades in 1988-92 and traditional black powder grenades in 1984-86 (IWC, 1987b) and 1988-92.

\begin{tabular}{|c|c|c|c|c|c|c|c|}
\hline \multirow[t]{2}{*}{ Grenade } & \multirow[t]{2}{*}{ Year } & \multirow{2}{*}{$\begin{array}{c}\text { No. of whales } \\
\text { shot }\end{array}$} & \multirow{2}{*}{$\begin{array}{c}\text { Percentage of } \\
\text { whales dead } \leq 5 \mathrm{~min}\end{array}$} & \multicolumn{4}{|c|}{ Survival time (min) } \\
\hline & & & & Median time & Lower quartile & Upper quartile & Maximum \\
\hline Penthrite & 1988 & 8 & 63 & 0 & 0 & 10 & 1440 \\
\hline Penthrite & $1989-1992$ & 30 & 37 & 15 & 0 & 45 & 150 \\
\hline Penthrite & $1988-1992$ & 38 & 45 & 15 & 0 & 34 & 1440 \\
\hline Penthrite* & $1988-1992$ & 31 & 35 & 15 & 0 & 53 & 1440 \\
\hline Black powder & $1984-1986$ & 38 & 24 & 80 & 8 & 180 & $>1440$ \\
\hline Black powder & $1988-1992$ & 38 & 18 & 57 & 15 & 90 & 360 \\
\hline \multirow[t]{2}{*}{ Black powder } & $1984-1986$ & & & & & & \\
\hline & $1988-1992$ & 76 & 21 & 62 & 15 & 144 & $>1440$ \\
\hline
\end{tabular}

* Seven whales reshot with penthrite grenades excluded from analyses.

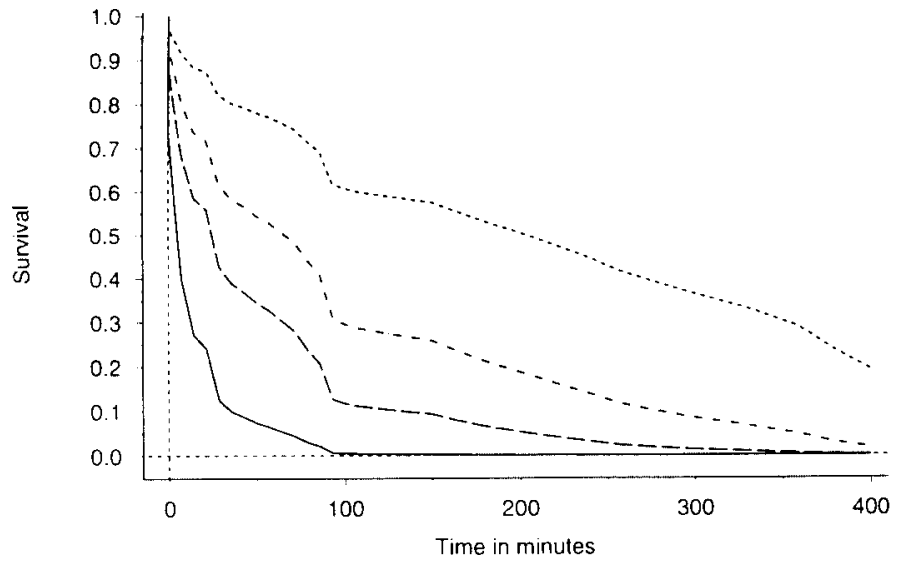

FIG. 4. Estimated survival plots for bowhead whales after hits with penthrite grenades and traditional black powder grenades, based on Cox regression for selected values of animal size. Solid line: Length $=8 \mathrm{~m}$, penthrite grenade; Long dash: Length $=8 \mathrm{~m}$, black powder grenade; Dot dash: Length $=18 \mathrm{~m}$, penthrite grenade; Short dash: Length $=18 \mathrm{~m}$, black powder grenade.

grenade, three with a single $15 \mathrm{~g}$ grenade, and one with one $10 \mathrm{~g}$ and two $15 \mathrm{~g}$ grenades. Three of the whales shot with one $10 \mathrm{~g}$ grenade died instantaneously or within five minutes. One whale swam under the ice and was retrieved and killed 60-75 minutes later using three black powder grenades. One whale, which was only wounded by the $10 \mathrm{~g}$ penthrite grenade, escaped but was retrieved and killed the following day by two $15 \mathrm{~g}$ penthrite grenades and five black powder grenades. Two of the three whales shot with a single $15 \mathrm{~g}$ penthrite grenade died instantaneously, and one died within ten minutes. One of the whales which died very quickly (from a $10 \mathrm{~g}$ grenade) was lost when the harpoon loosened. The average size of the landed whales was $9.3 \mathrm{~m}$ (range 7.7-13.3 $\mathrm{m}$ ).

In four of the six animals that died rapidly, the detonation site was recorded as the thorax, and the heart, lungs and arteries were damaged. In two of the six cases, the detonation site was near the thoracic spine. Post-mortem inspection of these animals showed massive injuries in the muscle and rib damage with profuse sub-pleural haemorrhaging. The muscle had a jelly-like consistency in an area up to $20-30 \mathrm{~cm}$ from the detonation site. Grenade fragments were found $20 \mathrm{~cm}$ from the detonation site, and shrapnel was located up to $2 \mathrm{~cm}$ inside bone. After detonation in the thoracic cavity, damage in the lungs, heart and larger vessels was registered in addition to massive intrathoracic, sub-pleural and mesenteric haemorrhaging. In the whale that swam under the ice, the grenade had detonated in the boundary between muscle and blubber below the thorax. However, in this case the propellant charge for the projectile was $25 \%$ to $30 \%$ larger than recommended. In the whale that escaped and was reshot the following day, at least two of the penthrite grenades had detonated peripherally in the body. The third was never found.

Three of the whales that died very rapidly had been hit by one black powder grenade from a shoulder gun in addition to penthrite grenades. The post-mortem inspections showed that in one of the whales, the black powder grenade had detonated in the thorax; in the second whale, it was found undetonated in the abdomen; and in the third whale, partly detonated in the musculature. In one whale six to seven black powder grenades had been used before one $15 \mathrm{~g}$ penthrite grenade was used to kill the whale instantaneously. One of the black powder grenades used for this whale had detonated in the lungs without killing the animal.

Data for the ratio of animals lost for penthrite and black powder grenades are available only up to spring 1990. From 1988 to spring 1990,31 whales were shot with penthrite grenades and 54 with black powder grenades (Department of Wildlife Management, 1990). Six (19\%) of the 31 whales struck with penthrite grenades and $16(30 \%)$ of the 54 whales struck with black powder grenades were lost. For the individual years, the proportions lost were as follows: 13\%, 25\% and $18 \%$ respectively for penthrite grenades and $24 \%, 36 \%$ and $31 \%$ respectively for black powder. In 1984-86, 39\% of whales struck with black powder grenades were lost, and the figures for each of the years were 52\%, 35\% and 29\%, respectively (George et al., 1990).

\section{DISCUSSION}

There was a marked increase in the proportion of bowhead whales that died instantaneously or quickly ( $\leq 5 \mathrm{~min})$ and a marked reduction in survival times when penthrite grenades were used instead of the traditional black powder grenade, 
even though a few animals lived for a long time after being shot with penthrite grenades (Table 1). The difference between the two types of grenades is apparent from the survival curves (Fig. 3), which show the percentage of animals surviving as a function of time after shooting.

In 1988 the penthrite charges were $10 \mathrm{~g}$ and $15 \mathrm{~g}$. These charges were determined partly on the basis of experience in hunting other whale species and partly on safety considerations. Previous experiments had shown that 20-22 g penthrite is adequate to cause instantaneous death not only in minke whales (Øen, 1985) but also in the large fin and sei whales (Øen, 1987). Since the shot could be placed quite accurately in the animal in the bowhead whale hunt, it was considered wise on safety grounds to reduce the amount of explosive in the bomb until more practical experience had been accumulated.

The limited material from 1988 did not show any apparent difference in the effect of the $10 \mathrm{~g}$ and $15 \mathrm{~g}$ charges. When the penthrite charge was increased to $20 \mathrm{~g}$ from 1989 on, the result was not an increase, but rather a decrease in the percentage of instantaneous death. Survival times were also longer compared with the 1988 results (Table 1). As a larger charge widens the area in which detonation causes instantaneous or rapid death, the most likely reason for these apparently contradictory results seems to be the incompleteness of the data for 1989-92 rather than differences in effectiveness (Øen, in press).

Although the number of animals obtained during the 1988 hunting trials was limited, all information given by the hunters concerning impact point, effect of the detonation, number of shots, survival times, etc., was recorded as soon as the whales had been landed and could be compared with the findings of the post-mortem examination.

The quality of the data for 1989-92 is poorer than for 1988, and it is more difficult to decide with certainty how representative the data are. From 1989 on, data were not collected systematically; data was not recorded on all the whales shot with penthrite grenades during this period. The survival times that were recorded could not be evaluated with respect to impact point or confirmed by post-mortem examination, and the reports given by telephone might have been imprecisely or incorrectly recorded. Furthermore, the prototype grenades constructed for the 1989 season were, on the basis of the favourable results from 1988, distributed to new users without giving them any organized instruction, and incorrect weapons and propellant charges were used. Such errors must have affected the results, but cannot be quantified. There is also reason to believe that data were to a certain extent recorded selectively: for example, in 1991 the only survival times recorded for penthrite grenades were for those that did not function properly: in other words, the reports were a form of complaint about the new grenades. Despite the small number of whales taken in 1988, it is therefore reasonable to be more cautious in drawing conclusions from the 1989-92 data than from the 1988 data.

Taking into account the reservations discussed above, the results indicate that penthrite grenades were more effective and killed bowhead whales faster than traditional black powder grenades. For the 38 whales killed by black powder grenades in 1984-86, both the median and the upper quartile of the survival times were considerably longer than in 1988-92 (Table 1). However, if we compare the survival plot for black powder for $1984-86$, which represents $88 \%$ of the whales landed during the period, and the survival plot for 1988-92, which represents more than a quarter of the whales landed, the two curves are almost identical, except that the graph for 1988-92 has a break at $90 \mathrm{~min}$. There is no technical or biological reason why a larger proportion of the whales should die after 90 min in 1988-92 than in 1984-86. The explanation must be that survival times were rounded down to $90 \mathrm{~min}$ in cases where the actual time was uncertain, but exceeded 1.5 hours. Without this, the true value for the upper quartile would, according to the survival curve, have been roughly 150-180 min in 1988-92 as well, and about 150 min for the two periods pooled (Fig. 3). The survival curve for penthrite grenades shown in Figure 3 includes seven whales which were first shot with several (3-9) black powder grenades but appeared to be only lightly wounded. If these whales had been excluded, the curve would have been only marginally different.

More rapid killing should help to prevent whale loss. This is indicated in the decreased struck-and-lost rate which occurred when penthrite grenades were used in the hunt instead of black powder grenades.

No technical problems with penthrite grenades or the safe and arming mechanism were recorded in 1988, but a total of nine grenades produced after 1988 were reported not to have functioned satisfactorily. The problems noted were the projectile breaking in two on hitting bone, premature detonation $(<3 \mathrm{~s})$ or failure of the fuse to detonate the penthrite charge. Inspection of the projectiles showed that, most probably, malfunctioning occurred because (a) an incorrect propellant charge was used, (b) a production fault resulted in too weak a front plug (Fig. 2b) or (c) corrosion had occurred within the fuse. The front plug is now modified and made of stainless steel. Work on preventing corrosion within the fuse has begun, and new fuses made of titanium are planned to be tested in hunting trials in 1995.

Three cases were reported in which the grenade did not penetrate the blubber of the whale completely. Both the shape of the projectile and the properties of bowhead skin and blubber have been considered as possible reasons. Although these factors cannot be ruled out, the data give little or no grounds for such conclusions, since the penthrite grenades functioned correctly in very large animals $(19.8 \mathrm{~m})$. The most likely reasons for poor penetration are the same as the reasons for malfunction as well as the use of poor sealant packings (leather washers) that leaked gas and thus reduced velocity and penetrative ability. Further studies of possible reasons for insufficient penetration will be made, including shooting trials at Barrow.

Malfunctioning of the black powder grenade, gun or propellant charge was not unusual; cases were mentioned in several hunting reports to the AEWC. According to one of these reports, as many as five of eight black powder grenades 
failed to function in the hunt of one whale. In the 1984-86 hunting seasons, $18 \%$ of the black powder grenades malfunctioned (IWC, 1987b).

If the whale is not killed by the first shot, further shots are necessary. Repeated shots can be fired with a reserve darting gun kept ready and loaded or with a shoulder gun, which is a faster weapon. The shoulder gun is used more or less routinely after the darting gun has been fired. The average number of black powder, shoulder-gun grenades used is about 3.5 per whale, although as many as 24 black powder grenades were registered in one whale. This apparent overuse of the shoulder gun can be attributed to the unpredictable weather and ice conditions, which make losses more likely. It is also logical to fire too many rather than too few shots, since the hunters know from experience that the grenades do not always work satisfactorily.

\section{RECOMMENDATIONS AND CONCLUSIONS}

Although the data are incomplete, the hunting trials have shown that the traditional killing methods for bowhead whales can be improved. However, to achieve the best possible result, other important factors must also be optimized. In addition to the introduction of new grenades, the other hunting equipment should be modernized to some extent, and the hunters should receive better instruction. These steps in combination would result in a general reduction of survival times and whale losses.

The darting gun used for the first strike achieved its present form in the last century and is ideal for this unique type of hunting. It is doubtful whether the weapon itself can be made more effective. However, the propellant charge should be standardized.

A penthrite grenade combined with the shoulder gun as a secondary weapon would probably be extremely effective in the bowhead whale hunt and would probably result in a faster kill. Technically, it would be relatively simple to adapt penthrite grenades to this gun, but many weapons are very old and it is uncertain how much pressure they can withstand. In addition, when the weapon is fired it gives a powerful recoil, which hunters attempt to reduce by paring down the leather packing of the grenade so that some of the gas from the propellant can escape past the projectile. This can reduce momentum so much that the grenade fails to penetrate adequately, and with a more powerful grenade it can represent a safety problem. Before the penthrite grenade is considered for the shoulder gun, an entirely new type of shoulder gun with adequate pressure tolerance and suitable recoil properties should be designed. The propellant charge for the shoulder gun should also be standardized and possibly prefabricated.

The harpoon currently used in the bowhead whale hunt does not kill the whale, but only anchors the buoy to the whale: it can only be described as poor. It is not uncommon for the harpoon to pull out of the whale, which is probably an important reason why some wounded animals escape and some dead animals are lost (Follmann and Manning, 1989).
A harpoon that penetrates deeper and is more firmly anchored would prevent the loss of some animals.

The following conclusions may be drawn on the basis of the results discussed here. Despite the weaknesses of the data and the fact that the penthrite grenades used up to 1992 were prototypes that were not fully developed when introduced into the ordinary hunt, a higher percentage of the whales died instantaneously or rapidly $(\leq 5 \mathrm{~min})$ when penthrite grenades were used rather than black powder grenades. Whales that survived more than 5 min were also killed more rapidly by penthrite grenades than by black powder grenades. This was probably also why the proportion of losses was lower than with the traditional black powder grenade. However, the extreme climatic conditions and the very specialized hunting technique for which the grenades are used require high safety and technical standards. Although both the tests and experience from the hunt showed that functional reliability and personnel safety were probably improved by the use of penthrite grenades, it is advisable to carry out further tests under controlled conditions similar to those in 1987 and 1988 before the new grenades are taken into large-scale use. Improvements of the weapons (especially the shoulder gun), the propellant charges and the harpoon should also be considered. Furthermore, a training and instruction programme for all users, similar to that held in 1988, should be held before new technology and hunting equipment are introduced into the hunt.

\section{ACKNOWLEDGEMENTS}

I would like to thank the Chairman of the Alaska Eskimo Whaling Commission (AEWC), B. Rexford, and the Chairman E. Itta and members of the AEWC WIP Management Committee, A. Brower Jr. and Special Project Coordinators B. Adams and Dr. H. P. Huntington, J. Lefevre and L. Sutcliffe for valuable discussions and help in organizing the project. Thanks also to Director B. Nageak of the North Slope Borough's Department of Wildlife Management in Barrow, Alaska for his helpfulness during the author's stay at the department. A special thank you is due to Dr. T.F. Albert at the same department for generous professional help, support, and encouragement and to his colleagues Dr. M. Philo and C. George for their help in collecting data from the hunt. Director K. Loftsson at Hvalur h.f. in Iceland placed whales, crews, equipment and accommodation at disposition during testing of the prototypes, and Mr. H.H. Henriksen of Henriksen Mechanical Workshop A/S, Tønsberg has been the most valuable partner during the development of the penthrite grenade. The author also wishes to thank Dr. L. Walløe of the Department of Physiology, University of Oslo, for his support, encouragement, valuable discussions, most valuable help in the statistical analysis of the data, and for comments on the manuscript; Mr. T. Dillingøen who made the drawings of Figures 1 and 2 on the basis of figures submitted by the AEWC, original photos, and models; and Ms. A. Coulthard, who corrected the English. 


\section{REFERENCES}

AEWC (Alaska Eskimo Whaling Commission). 1988. Video recordings from the AEWC Weapons Workshop, 9-11 February 1988, Barrow, Alaska. Archives of the Alaska Eskimo Whaling Commission, P.O. Box 570, Barrow, Alaska 99723, U.S.A.

- 1991. AEWC Management Plan. Report of the Annual Whaling Captains' Convention, 13-15 February 1991. Alaska Eskimo Whaling Commission, P.O. Box 570, Barrow, Alaska 99723, U.S.A.

BAYTOS, J.F. 1980. Pentaerythritol-tetranitrate (PETN). In: Gibbs, T.R., and Populato, A., eds. LASL Explosive Property Data. Berkeley: University of California Press. 130-140.

DEPARTMENT OF WILDLIFE MANAGEMENT. 1990. Archives Memo of the 19 June 1990. Department of Wildlife Management, North Slope Borough, P.O. Box 69, Barrow, Alaska 99723, U.S.A.

DOBRATZ, B.M. 1981. LLNL explosives handbook. Properties of chemical explosives and explosive simulants. Lawrence Livermore Laboratory, University of California, Livermore, California 99550, U.S.A. Available from National Technical Information Service, U.S. Department of Commerce, 5285 Port Royal Road, Springfield, Virginia 22161, U.S.A.

EBERHARDT, L.L., and BREIWICK, J.M. 1992. Impact of recent population data on historical population levels of bowhead whales inferred from simulation studies. Report of the International Whaling Commission 42:485-489.

FOLLMANN, E.H. 1989. Radio and ultrasonic telemetry applied to the subsistence hunt of bowhead whales in Alaska. Proceedings of the International Symposium on Biotelemetry 10:296-303.

FOLLMANN, E.H., and MANNING, A.E. 1989. The use of radio telemetry as an aid in the retrieval of bowhead whales (Balaena mysticetus) struck during the annual Eskimo subsistence hunt in Alaska. Arctic 42(3):189-198.

FRAKER, M.A., and BOCKSTOCE, J.R. 1980. Summer distribution of bowhead whales in the eastern Beaufort Sea. Marine Fisheries Review 42:57-64.

GEORGE, J.C., CARROLL, G.M., PHILO, L.M., and ALBERT, T.F. 1990. Report of field activities of the spring 1988 census of bowhead whales (Balaena mysticetus) off Point Barrow, Alaska with observations on the subsistence hunt. Report of the International Whaling Commission 40:383-391.

IWC (International Whaling Commission).1985. Report of the weapons improvement for the Alaska Eskimo harvest of bowhead whales. Report presented to the International Whaling Commission, Technical Committee. Report No. TC/37/AS5. 4 p.

- 1986. Hunting efficiency and recovery methods developed and employed by Alaska Eskimos in the hunt of the bowhead whale. Report presented to the International Whaling Commission, Technical Committee. Report No. TC/38/HK2A. 8 p.

. 1987a. Chairman's Report of the Thirty-Seventh Meeting. Humane killing. Report of the International Whaling Commission $37: 21$.

. 1987b. "Time to death" of landed bowhead whales and related data analysis of whale shells used by Alaska Eskimo subsistence whalers. May 1987. Report to the International Whaling Commission, Technical Committee. Report No. TC/39/HK1.11 p. 1992a. Chairman's Report of the Forty-Second Meeting. Report of the Scientific Committee. Report of the International Whaling Commission 42:137-152.

1992b. Chairman's Report of the Forty-Second Meeting. Report of the Scientific Committee. Report of the International Whaling Commission 42:60-64.

- In press. Chairman's Report of the Forty-Fourth Meeting. Report of the International Whaling Commission 44.

KANO, H., and HASUI, S. 1982. Japan's experiments on humane methods of catching whales during the 1981/82 season. Report to the International Whaling Commission, Scientific Committee. Report No. SC/34/O18. 39 p.

LYTLE, T.G. 1984. Darting guns, darting-gun harpoons, and bombs. In: Harpoons and other whalecraft. New Bedford, Massachusetts: The Old Dartmouth Historical Society. 60-119.

MITCHELL, E., and REEVES, R.R. 1980. The Alaska bowhead problem: A commentary. Arctic 33(4):686-723.

NAVAL COMPANY. n.d.a. Instructions for "bridger" darting guns. Unpubl. Available from Naval Company, Inc., 4747 Cold Spring Creamery Road, R.D. 2, Doylestown, Pennsylvania 18901, U.S.A.

- n.d.b. Instructions for loading darting gun cartridges. Unpubl. Available from Naval Company, Inc., 4747 Cold Spring Creamery Road, R.D. 2, Doylestown, Pennsylvania 18901, U.S.A.

ØEN, E.O. 1984. Progress report on research in 1983-84 to develop more humane killing methods in Norwegian whaling. Report to the International Whaling Commission, Technical Committee. Report No. TC/36/HK1. 10 p.

1985. Progress report on research in $1984-85$ to develop more humane killing methods in Norwegian whaling. Report to the International Whaling Commission, Technical Committee. Report number IWC/37/19. 4 p.

- 1987. Progress report on penthrite as detonating charge in grenades for $90 \mathrm{~mm}$ harpoons. Report to the International Whaling Commission, Technical Committee. Report No. TC/39/HK4. 3 p.

- 1988a. Manual for transport, handling, assembling and dismantling of the dart for darting guns. Contribution to the AEWC Weapons Workshop, 9-11 February 1988, Barrow, Alaska. Unpubl. ms. Available from E.O. Øen, Norwegian College of Veterinary Medicine, P.O. Box 8146, Dep, 0033 Oslo, Norway.

. 1988b. Fuse and grenade. Design and function. Contribution to the AEWC Weapons Workshop, 9-11 February 1988, Barrow, Alaska. Unpubl. ms. Available from E.O. Øen, Norwegian College of Veterinary Medicine, P.O. Box 8146, Dep, 0033 Oslo, Norway.

. 1994. A Norwegian penthrite grenade for minke whales: Development, model description and results of hunting trials with Norwegian prototypes and a modified Japanese penthrite grenade in 1983. Unpub. ms. Available from E.O. Øen, Norwegian College of Veterinary Medicine, P.O. Box 8146, Dep, 0033 Oslo, Norway.

- In press. A Norwegian penthrite grenade for minke whales: Hunting trials with prototypes and results from the hunt in 1984, 1985 and 1986. Acta Veterinaria Scandinavica 36(1). 
REEVES, R.R., and LEATHERWOOD, S. 1985. Bowhead whale, Balaena mysticetus Linnaeus, 1758. In: Ridgway, S.H., and Harrison, R., eds. Handbook of marine mammals, Vol 3: The sirenians and baleen whales. London: Academic Press. 305-344.
TILLMAN, M.F. 1980. Introduction: A scientific perspective of the bowhead whale problem. Marine Fisheries Review 42:2-5. 